Available online at GSC Online Press Directory

GSC Biological and Pharmaceutical Sciences

e-ISSN: 2581-3250, CODEN (USA): GBPSC2

Journal homepage: https://www.gsconlinepress.com/journals/gscbps

(RESEARCH ARTICLE)

\title{
Phytochemical composition of desert date kernel (Balanites aegyptiaca) and the physical and chemical characteristics of its oil
}

\author{
Datti Yau 1, ${ }^{*}$, Tijjani Yahya Ahmad ${ }^{1}$, Koki Isa Baba ${ }^{1}$, Ali Usman Lado ${ }^{1}$, Labaran Musbahu ${ }^{1}$, Ahmad Ummi \\ Umar $^{2}$ and Tasi'u Nura ${ }^{3}$
}

${ }^{1}$ Department of Chemistry, Yusuf Maitama Sule University, Kano.

2 Department of Science Laboratory Technology, School of Technology Kano.

${ }^{3}$ Department of Chemistry, School of Science Education, FCE (T) Bichi.

Publication history: Received on 08 June 2020; revised on 26 June 2020; accepted on 27 June 2020

Article DOI: https://doi.org/10.30574/gscbps.2020.11.3.0166

\begin{abstract}
The desert date (Balanites aegyptiaca) is an important tree found in some African countries. In this study the phytochemical composition of the desert date kernel and some physical and chemical properties of its oil were analyzed using standard procedures. The results of the phytochemical screening revealed the presence of alkaloids, saponins, flavonoids, tannins, steroids and glycosides. While the results for the physical analysis of the kernel oil revealed the following: Color, pale yellow; density, $0.910 \mathrm{~g} / \mathrm{cm}^{3}$; specific gravity, 0.907; refractive index, 1.458; and viscosity, 19.68 . And on the other hand, the results for the chemical analysis of the kernel oil revealed the following: Acid value, 3.06 $\mathrm{mgKOH} / \mathrm{g}$; free fatty acid, 1.27; peroxide value, $3.71 \mathrm{mEq} / \mathrm{Kg}$; saponification value, $198 \mathrm{mg} / \mathrm{KOH} / \mathrm{g}$; and iodine value, $98.73100 / \mathrm{g}$. All the results were compared and found to be within the FAO/WHO standards.
\end{abstract}

Keywords: Desert date; Kernel; Phytochemical composition; Chemical characteristics

\section{Introduction}

Desert date (Balanite aegyptiaca Linn.) is an important multipurpose tree found in most African countries (Clement et al., 2011). Balanites Aegyptica has multiple applications with almost every part of the plant being useful. The tree is actually valued more for its fruits and seeds: The fruits and kernel are widely used in many ways in different countries including Nigeria especially during the dry season and drought periods (Lockett et al., 2000). The kernel of this plant is traditionally used in the treatment of various ailments such as jaundice, intestinal worm infection, malaria, syphilis, epilepsy, dysentery, constipation, haemorroid among others (Daya and Vaghasiya, 2011). The stem of the plant is used as timber, poles, charcoal, firewood, fodder, food (Elseed et al., 2002), gum, shade, gum and windbreak (Guinand and Lemessa 2001). The plant may be grown for its fiber, oil and/or for medicinal values. It is also used in treatment of several diseases and disorders since ages.

Balanites Aegyptica fruit is readily available in northern Nigeria and the seed which is obtained after it is being sucked is seen as a nuisance along markets and settlements in communities (Jock 2017). This is because no suitable application for the seed kernel has been found in most developing countries. However, the seed kernel oil of Balanites aeyptiaca is a good source of raw material for food, cosmetic and pharmaceutical industries (Jock 2017).

This multipurpose tree is used for food and fodder in almost all parts of Africa and South Asia (Billore 1988; Elseed et al., 2002). Among the various useful parts of the plant, the fleshy pulp of the fruit is eaten fresh or dried; it also used as a food, beverage and medicines. The protein content of the fruit of this plant is believed to be superior to that in guava,

\footnotetext{
* Corresponding author: Datti Yau
} 
mango, banana and papaya. The fleshy fruit contains high carbohydrates and steroidal saponins (Al-Thobaiti and AbuZeid 2018), vitamin A, vitamin C and other essential minerals for human. Seed kernel also widely used for oil. The kernel produces high quality edible oil (Obidah et al., 2009) with large number of medicinal properties (Hanan et al., 2009), and is also rich in protein and minerals contents (Elfeel and Warrag, 2011). In quality aspect, it is similar to sesame and groundnuts oils (Abu Al-Futuh, 1983; Obidah et al., 2009), with the oil used as a biodiesel (Chapagain et al., 2009; Gutti et al., 2012; Kumawat et al., 2012).

The aim of this study is to determine the phytochemical constituents of desert date kernel Balanites aegyptiaca, and also to investigate the physical and chemical characteristics of the desert date kernel oil.

\section{Material and Methods}

\subsection{Sample Collection and Preparation}

The fruits of Balanites aegyptiaca (desert date) were purchased from Rimi market in Kano State, Nigeria and brought to the department of Biological Sciences, Yusuf Maitama Sule University, Kano, for identification by a plant taxonomist. The plant was identified and authenticated and issued a voucher specimen number YUHAN 0058. The fruits were crushed using a steel hammer to obtain the kernels, which were then air-dried and then ground using mortar and pestle (Bayero et al., 2019). The ground kernel was then packed in an air tight container and then stored in a desiccator (containing silica gel) ready for further analysis.

All the chemicals and reagent used were of analytical grade.

\subsection{Extraction of the Sample}

The powdered sample (50 g) was soaked in $300 \mathrm{ml}$ of absolute ethanol for $72 \mathrm{hrs}$, and stored away from direct light. The supernatant was decanted and filtered using filter paper and the filtrate was evaporated to dryness, and then stored in sample bottles at room temperature to avoid any biological degradation (Bayero et al., 2019).

\subsection{Phytochemical Analysis}

The crude ethanol extract was phytochemically screened for the presence of secondary metabolites such as alkaloids, saponins, phenols, flavonoids, tannins, steroids, reducing sugars, terpenoids, glycosides, volatile oils and anthraquinones in accordance with standard methods by Harborne (1998) with slight modifications by Tripathi and Mishra (2015) and Alhassan et al., 2018.

\subsubsection{Test for Alkaloids}

The ethanol extract ( $2 \mathrm{~g}$ ) was dissolved in dilute $1 \%$ hydrocloric acid and filtered.

Mayer's Test: A portion of the filtrate $(1 \mathrm{ml})$ was treated with 4 drops of Mayer's reagent (potassium iodide). Formation of white or pale yellow precipitate indicates the presence of alkaloids.

\subsubsection{Test of Saponin}

Froth Test: A portion of the ethanol extract $(2 \mathrm{ml}$ ) was diluted with distilled water to $5 \mathrm{ml}$ and then shaken in a graduated cylinder for 5 minutes. Formation of honeycomb froth confirms the presence of saponin.

\subsubsection{Test for Phenols}

A portion of ethanol extract $(2 \mathrm{ml})$ was treated with 4 drops of ferric chloride $\left(\mathrm{FeCl}_{3}\right)$ solution. Formation of a bluegreen colour confirms the presence of phenols.

\subsubsection{Test for Flavonoids}

Alkaline Reagent Test: A fraction of the extract $(2 \mathrm{ml})$ was treated with 4 drops of $1 \%$ sodium hydroxide. Formation of yellow colour indicates the presence of flavonoids.

\subsubsection{Test for Tannins}

Lead Acetate Test: A portion of the filtrate $(1 \mathrm{ml})$ was treated with 3 drops of $1 \%$ lead acetate in a test tube. Formation of a blue-black colour indicates the presence of tannins. 


\subsubsection{Test for Steroids}

Salkowski Tests: Chloroform ( $5 \mathrm{ml}$ ) was added to $0.5 \mathrm{ml}$ of the filtrate in a test tube, and then an equal volume of concentrated sulphuric acid $(5 \mathrm{ml})$ was added by the sides of the test tube. Formation of a red colour on standing indicates the presence of steroids.

\subsubsection{Test for Reducing Sugars}

Benedict's Test: Benedict's solution ( $2.5 \mathrm{ml}$ ) was added to the extract $(1 \mathrm{ml})$ in a test tube, and then warmed over water bath for about 5 minutes. Formation of a green, red or yellow coloration indicates the presence of reducing sugar.

\subsubsection{Test for Terpenoids}

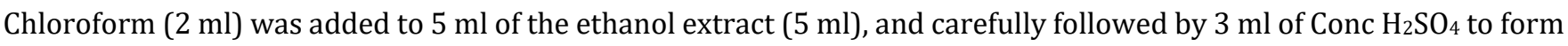
a layer. Appearance of a reddish brown coloration indicates the presence of terpenoids.

\subsubsection{Test for Glycosides}

The sample extract ( $5 \mathrm{ml}$ ) was mixed with $2 \mathrm{ml}$ of glacial acetic acid containing 1 drop of $\mathrm{FeCl}_{3}$ solution, and then $1 \mathrm{ml}$ of Conc. $\mathrm{H}_{2} \mathrm{SO}_{4}$ was further added. Formation of a brown ring of interface indicates the presence of glycosides.

\subsubsection{Test for Volatile Oils}

Five (5) grams of the ethanol extract was dissolved in $90 \%$ alcohol and 4 drops of ferric chloride were added. Formation of green coloration indicates the presence of volatile oils.

\subsubsection{Test for Anthraquinones}

Sulphuric acid $(10 \mathrm{ml})$ was added to $0.5 \mathrm{~g}$ of the extract and then boiled and filtered while hot. The filtrate was further shaken with $5 \mathrm{ml}$ of chloroform, and the chloroform layer transferred to another test tube and $1 \mathrm{ml}$ of dilute ammonia solution was added. Formation of a pink, red or violet colour indicates the presence of anthraquinones.

\subsection{Extraction and Purification of the Oil}

The oil was extracted from the kernels of the desert date using the solvent extraction process, using petroleum ether as a solvent by soxhlet apparatus (Karamat et al., 2003; Adejumo et al., 2013; Ratna et al., 2014). For purification, the oil was taken in a separating funnel along with water $(100 \mathrm{ml})$, ether $(200 \mathrm{ml})$ and saturated sodium chloride the content was well shaken and then allowed to stand. The aqueous layer was then discarded and the process was repeated three times with organic layer. Finally the ethereal extract was taken in a conical flask and then dried over 20 g anhydrous sodium sulfate and was evaporated at a temperature of $40^{\circ} \mathrm{C}$ to get the purified oil (Karamat et al., 2003; Ratna et al., 2014).

\subsection{Physical Characteristics of the Oil}

\subsubsection{Color of Oil}

The color of the extracted oil from the desert date kernel was observed visually as reported by Ogala et al., (2018).

\subsubsection{Determination of Density and Specific Gravity of the Oil}

The density of the desert date oil was determined using pre-washed, dried and labeled density bottles. The density bottled was then filled up to the volume mark with the oil sample, and the weight of the density bottle with the oil was determined. The density bottled was also filled up to the volume mark with the water, and the weight of the density bottle with the water was determined (Myles 2001; Brosk 2014). The density and the specific gravity of the oil were calculated using the formulae:

$$
\begin{gathered}
\text { Density }=\frac{W 2-W 1}{V} \\
\text { Specific Gravity }=\frac{W 2-W 1}{W 3-W 1}
\end{gathered}
$$

Where; 
W1 = Weight of Empty Density Bottle

W2 $=$ Weight of Density Bottle + Oil

W3 = Weight of Density Bottle + Water

$\mathrm{V}=$ Volume of Oil.

\subsubsection{Refractive Index of the Oil}

The refractive index of the oil was determined using Abbe-60 refractometer (NYRL 3-Leica Mark, Leica Inc., Buffalo, New York) as described by AOAC (2008).

\subsubsection{Viscosity of the Oil}

The viscosity of the oil sample was investigation using the Ostwald-U-tube viscometer according to AOAC (2008). The viscometer was first suspended in a constant temperature water bath so that the capillary was vertical. The instrument was filled with the oil to the mark at the top of the lower reservoir with the aid of a pipette inserted in the side arm in such a way that the tube wall above the mark was not wetted. The instrument was then left to stand for 3 minutes before reading in order to equilibrate the sample temperature with that of the instrument $\left(35^{\circ} \mathrm{C}\right)$. By means of pressure on the respective arm of the tube, the oil moved into the other arm so that the meniscus was above the mark at the top of upper reservoir. Finally, the liquid was allowed to flow freely through the tube and the time required for the meniscus to pass from the mark above the upper reservoir to that at the bottom of the upper reserve was recorded.

\subsection{Chemical Characteristics of B. aegyptiaca Kernel Oil}

\subsubsection{Acid Value of the Oil}

Here $2 \mathrm{~g}$ of the test sample was transferred into a conical flask, and then $50 \mathrm{~cm}^{3}$ petroleum ether added and gently mixed. Ethanol $\left(50 \mathrm{~cm}^{3}\right)$ was then added into the mixture and titrated with $0.1 \mathrm{M} \mathrm{KOH}$ to pink colour (AOAC, 2008). The Acid value was calculated using the formula:

$$
\begin{gathered}
\text { Acid Value }(\mathrm{mg} \mathrm{KOH} / \mathrm{g})=\frac{\text { Titre Value } x \text { Normality } x 56.1}{\text { Weight of Sample }} \\
\% \text { Free Fatty Acid }=\frac{\text { Titre Value } x 28.2 \times \text { Normality }}{\text { Weight of Sample }} \\
1 \mathrm{~cm}^{3} \text { of } 1 \mathrm{M} \mathrm{KOH}=56.1 \mathrm{mg} \text { of } \mathrm{KOH}
\end{gathered}
$$

\subsubsection{Peroxide Value of the Oil}

The peroxide value (PV) of desert date kernel oil was determined according to the procedure reported by Wail et al., (1995) and adopted by Mohamed and Mohammed (2018), where $1 \mathrm{~g}$ of the test sample was transferred into $250 \mathrm{ml}$ conical flask, then $30 \mathrm{ml}$ of a glacial acetic acid/chloroform solution (ratio 3:2) was added, and the flask was gently shaken until the sample was dissolved, and then $0.5 \mathrm{ml}$ of saturated potassium iodide was added. The solution was one again gently shaken for 1 minute, and $30 \mathrm{ml}$ of distilled water was added followed by $0.5 \mathrm{ml}$ of $1 \%$ starch solution. The content of the flask was later titrated with $0.1 \mathrm{~N}$ sodium thiosulphate with constant and vigorous shaking until the blue colour just disappeared. A blank test was also carried out in similar manner. The volume of the $0.1 \mathrm{~N}$ sodium thiosulphate required was recorded.

$$
P V=\frac{(V a-V b) N X 100}{W}
$$

Where;

$\mathrm{Va}=$ Volume of sodium thiosulphate solution used in the titration

$\mathrm{Vb}=$ Volume of sodium thiosulphate solution used in the blank test

$\mathrm{W}=$ Weight of the sample in grams

$\mathrm{N}=$ Normality of sodium thiosulphate.

\subsubsection{Saponification Value of the Oil}

Determination of the saponification value of the desert date kernel oil was carried out according to the AOAC (2008) method, where $1 \mathrm{~g}$ of the oil sample was transferred into $200 \mathrm{ml}$ conical flask, and the $25 \mathrm{ml}$ of $0.1 \mathrm{~N}$ alcoholic $\mathrm{KOH}$ 
solution was added. The flask and its content were boiled under reflux for one hour with frequent rotation, then $1 \mathrm{ml}$ of phenolphthalein indicator was added while the solution was still hot, and the excess alkali was titrated with $0.5 \mathrm{~N} \mathrm{HCl}$, with the volume of $\mathrm{HCl}$ required to complete the titration recorded. The same procedure was repeated for the blank and the volume of $\mathrm{HCl}$ required to complete the titration also recorded.

$$
\text { Saponification Value }=\frac{(b-a) \times 0.02805 \times 1000}{S}
$$

Where;

$\mathrm{a}=$ Volume of $\mathrm{HCl}$ used to titrate the sample

$\mathrm{b}=$ Volume of $\mathrm{HCl}$ used to titrate the blank

$\mathrm{S}=$ Weight of oil in gram.

\subsubsection{Iodine Value of Oil}

The iodine value (IV) of the oil sample was determined according to the BSI (1985) method as adopted by Mohamed and Mohammed (2018), where $0.26 \mathrm{~g}$ of the sample was weighed into a glass stoppered flask and then dissolved with $10 \mathrm{ml}$ cyclohexane. Then $20 \mathrm{ml}$ of Wijs solution (iodine monochloride dissolved in acetic acid) was added and the flask was stoppered and then allowed to stand in the dark for 30 minutes at a temperature of $25^{\circ} \mathrm{C}$ after which $20 \mathrm{ml}$ of $10 \%$ potassium iodide solution was added. The mixture was then titrated against $0.1 \mathrm{M} \mathrm{Na}_{2} \mathrm{~S}_{2} \mathrm{O}_{3}$ using starch as the indicator. The analysis was then carried out using a blank, and the iodine value was calculated using the following formula (AOAC, 2008).

$$
\text { Iodine Value }=\frac{12.69 \times C(V 1-\text { V2) }}{\text { Weight of Sample in gram }}
$$

Where;

$\mathrm{C}=$ Concentration of $\mathrm{Na}_{2} \mathrm{~S}_{2} \mathrm{O}_{3}$ solution,

$\mathrm{V} 1$ = Volume of $\mathrm{Na}_{2} \mathrm{~S}_{2} \mathrm{O}_{3}$ used for the blank,

$\mathrm{V} 2=$ Volume of $\mathrm{Na}_{2} \mathrm{~S}_{2} \mathrm{O}_{3}$ used for the sample

\subsubsection{Determination of Fat Content}

The Gerber method for the determination of the fat content of the desert date kernel oil was employed in accordance with the procedure reported by Richardson, (1985) and adopted by Gemechu et al., (2015). Here 5 ml of each of the oil sample was mixed with $10 \mathrm{ml}$ of sulphuric acid (specific gravity 1.82) into butyrometer and $1 \mathrm{ml}$ of amyl alcohol was then added. The butyrometer was then closed with rubber cork, and the content was vigorously shaken until all the oil was digested by the acid. The butyrometer was then placed in a water bath at $65^{\circ} \mathrm{C}$ for 5 minutes. The sample was centrifuged for 5 minutes, and then transferred back to the water bath at $65^{\circ} \mathrm{C}$ for 5 minutes, and the percentage fat was recorded from the butyrometer.

\subsubsection{Free Fatty Acid (FFA) of the Oil Sample}

To determine the free fatty acid content of the desert date kernel oil, $2 \mathrm{~g}$ of the oil was placed in a $250 \mathrm{ml}$ conical flask and warmed, and $2.5 \mathrm{~mL}$ of methanol was added with constant stirring, followed by 3 drops of phenolphthalein indicator, and this was then titrated against $0.14 \mathrm{M}$ potassium hydroxide solution with vigorous shaking until a permanent light pink color, which persisted for $1 \mathrm{~min}$, was observed (Afolabi, 2008; Ogala et al., 2018). The end point was recorded, and the free fatty acid value was calculated using equation.

$$
\% \text { Free Fatty Acid }=\frac{V x M \times 28.2}{W}
$$

Where;

$\mathrm{V}=$ Volume of potassium hydroxide used

$\mathrm{M}=$ Molarity of potassium hydroxide used

$\mathrm{W}=$ Weight of the Sample. 


\section{Results}

The results for the phytochemical constituent of the desert date kernel are presented in Table 1, while the physical and chemical characteristics of the desert date kernel oil are presented in Tables 2 and 3 respectively.

Table 1 Phytochemical Constituent of the Kernel of the Desert Date

\begin{tabular}{lll}
\hline S/NO & Phytochemical & Observation \\
\hline 1 & Alkaloids & + \\
2 & Saponins & + \\
3 & Phenols & - \\
4 & Flavonoids & + \\
5 & Tannins & + \\
6 & Steroids & + \\
7 & Reducing Sugars & - \\
8 & Terpenoids & - \\
9 & Glycosides & + \\
10 & Volatile Oils & + \\
11 & Anthraquinones & - \\
\hline
\end{tabular}

Table 2 Physical Characteristics of the Oil

\begin{tabular}{llll}
\hline S/NO & Parameter & & FAO/WHO STANDARD \\
\hline 1 & Color & Pale Yellow & \\
2 & Density g/cm3 & 0.910 & 0.909 \\
3 & Specific Gravity & 0.907 & $0.9-1.16$ \\
4 & Refractive Index & 1.458 & $1.4677-1.4705$ \\
5 & Viscosity & 19.68 & 19.79 \\
\hline
\end{tabular}

Table 3 Chemical Characteristics of B. aegyptiaca Kernel Oil

\begin{tabular}{llll}
\hline S/NO & Parameter & Desert Date Kernel Oil & FAO/WHO Standard \\
\hline 1 & Acid Value $(\mathrm{mgKOH} / \mathrm{g})$ & 3.06 & 4 \\
2 & Free Fatty Acid & 1.27 & $5.78-7.28$ \\
3 & Peroxide Value (mEq/Kg) & 3.71 & $<10$ \\
4 & Saponification Value $(\mathrm{mg} / \mathrm{KOH} / \mathrm{g})$ & $198 \pm 0.16$ & $195-205$ \\
5 & Iodine Value $100 / \mathrm{g}$ & 98.73 & $80-106$ \\
\hline
\end{tabular}




\section{Discussion}

The results of phytochemical screening test of the desert date kernel oil revealed the presence of alkaloids, saponins, flavonoids, tannins, steroids, glycosides and volatile oils, while phenols, reducing sugars, terpenoids and anthraquinones were absent. These findings agree with many similar findings as reported by some researchers (Hanan et al., 2009; Yadav and Panghal 2010; Chothani and Vaghasiya 2011; Gupta et al., 2012; Kumawat et al., 2012; Jock 2017; Al-Thobaiti and Abu-Zeid 2018; and Selouka et al., 2020). These phytochemicals may be responsible for the application of the powdered kernel in treating certain skin infections (Daya and Vaghasiya 2011). Alkaloids may be toxic at a very high amount, but are often non-toxic and may have dramatic physiological activities hence they are widely used in medicine (Olaofe and Sanni, 1988). Lower doses of alkaloids have important pharmacological activities, such as reducing blood pressure, killing tumour cells, analgesic activity, stimulating circulation and respiration (Egbuna and Ifemeje 2015). Saponins are nonpoisonous to warm blooded animals, but at a high a high amount they are believed to cause gastroenteritis (Awe and Sodipo, 2001). Saponins have many health benefits which might have accounted for some of the reported therapeutic ability of Balanites aegyptiaca kernel (Gloria et al., 2011), including anti-inflammatory, anti-diabetic, anti-HIV, anti-atherosclerotic, hepatoprotective and hypolipidemic (Egbuna and Ifemeje, 2015). Flavonoids sometimes serve as flavoring ingredients of spices and vegetable (Olaofe and Sanni, 1988), but may also have protective effects including anti-oxidant, anti-inflammatory, anti-microbial, anti-viral, anti-allergic, anti-cancer and anti-diarrheal activities (Egbuna and Ifemeje 2015). Tannins, the water-soluble polyphenols are present in many plant foods, have been reported to be responsible for decreases in feed intake, feed efficiency, growth rate and protein digestibility. However, reports have indicated some carcinogenic activities of tannins (Chung et al., 1998). Steroids are known to possess many interesting medicinal, pharmaceutical and agrochemical activities, ranging from antibacterial, hepatoprotective, anti-tumor, antihelminthic, immunosuppressive, plant-growth hormone regulator, sex hormone, cytotoxic and cardiotonic activity (Patel and Savjani 2015). Glycosides family has been in clinical use for many years for the treatment of heart failure and atrial arrhythmia, and they are known to have a strong direct action on the heart and support and strengthen the rate of contraction (Vaidehi and Rajesh 2016). From ancient times, humans have used glycoside-containing plants and their crude extracts as arrow coatings, homicidal or suicidal aids, rat poisons and emetics, while in the modern times they have been adapted for the treatment of congestive heart failure and cardiac arrhythmia (Yubin et al., 2014). Volatile oils are also called essential oils or ethereal oils, and they are natural metabolic secretions of plants that are considered to be true plant hormones, as well as the fluid manifestations of the immune system of the plants, since they contribute to the removal of pests, attracting, instead, pollinating agents, which are some insects and birds (Monica and Ioan 2018). The most important feature of the volatile oils which gives them special economic value is their specific smell, and this form the basis for their use in perfumery, cosmetics and the food industry. Many essential oils have special therapeutic qualities, some of which have been known and used since ancient times (Monica and Ioan 2018).

The quality assessment of Balanites aegyptica kernel oil was carried out by analyzing some physical such as the oil color, its density, specific gravity, refractive index and viscosity. The observed colour of the oil was pale yellow, and this has been the findings of Ogala et al., (2018). The density of the kernel oil studied was found to be 0.910 which agrees with that reported by Babeker (2013) and just above that reported by Ogala et al., (2018) who reported 0.87, and just below than that reported by Manji et al., (2013) who reported a value of 1.001. However, the finding of this study is within the FAO/WHO standards of 0.909. The specific gravity of the desert date kernel oil in this study was found to be 0.907, and this result is in agreement with that reported by Jock (2011), Manji et al., (2013), Haftu, (2015), Sara and Mahdi (2016), Elbadawi et al., (2017), and within the 0.9-1.16 range set by the FAO/WHO standards. The refractive index of 1.458 is just a little below the FAO/WHO standard of 1.4677-1.4705, but still near similar to that reported by Babeker (2013) and Manji et al., (2013). The viscosity of 19.68 recorded in this however found to be in agreement with similar reports by Babeker (2013).

The acid value of $3.06 \mathrm{mgKOH} / \mathrm{g}$ and observed in this study is just below the FAO/WHO standard of $4 \mathrm{mgKOH} / \mathrm{g}$, but still shows that the oil is stable (Haftu 2015). While the free fatty acid content of $1.27 \%$ is far below the FAO/WHO standard limits of 5.78-7.28\%. Oils with high acid value (above $4 \mathrm{mgKOH} / \mathrm{g}$ ), also implying a high percentage free fatty acid content, will undergo rancidity due to the hydrolysis of the free fatty acids on storage. The acid value and the percentage free fatty acid of Balanites aegyptica seed kernel oil are all lower than FAO/WHO standard for edible oils. The lower the percentage free fatty acid content the less the tendency of the oil to undergo hydrolytic activities (Haftu 2015). However, the results for the acid value and the free fatty acids obtained in this study are in agreement with similar findings by Manji et al., 2013 and Jock 2017, but lower than that reported by Ogala et al., 2018.

The peroxide value, used as a measure of the extent to which rancidity reactions have occurred during storage, is used as an indication of the quality and stability of fats and oils. The peroxide value determined for the kernel oil of Balanites 
aegyptica was found to be $3.71 \mathrm{mEq} / \mathrm{g}$ and is within the FAO/WHO standard of less than $10 \mathrm{mEq} / \mathrm{g}$, and the lower the peroxide value the more suitable is the oil for a long storage due to low level of oxidative and lipolytic activities (Adegbe et al., 2016). The results of this study agree with similar reports by Mohammed et al., (2017) and Mohamed and Mohammed (2018), but far lower than reported by Babeker (2013) and Manji et al., (2013) who respectively reported 8.0 and $6.0 \mathrm{mEq} / \mathrm{g}$ ).

The saponification value, which is an index of average molecular mass of fatty acid in the oil sample, was found to be $198 \mathrm{mgKOH} / \mathrm{g}$ for Balanites aegyptica kernel oil analyzed, and this value is within the FAO/WHO range of 195-205 mg $\mathrm{KOH} / \mathrm{g}$ for edible oils. The result agrees with similar reports by Babeker (2013), Manji et al., (2013), Mohammed et al., (2017) and Mohamed and Mohammed (2018). The saponification value of oil is as an important parameter in determining the suitability of the oil for soap making.

The iodine value measures the degree of unsaturation in a fat or oil, and it determines the stability of oils to oxidation and allows the overall unsaturation of the fat to be determined qualitatively. The iodine value of the desert date kernel oil analyzed in this study was found to be $98.73100 / \mathrm{g}$ and within the range of the FAO/WHO standard of 80-106 100/g. The result was in agreement to similar reports by Babeker (2013), Manji et al., (2013), Mohammed et al., (2017) and Mohamed and Mohammed (2018). Oils with iodine values below 100 are non-drying, while those having values between $100-130$ are semi-drying and those with values above 130 are termed drying oils (Jock 2018).

\section{Conclusion}

This research analyzed the phytochemical properties of the seed kernel of Balanites aegyptiaca and the physical and chemical properties of the oil extracted from the seed. The results suggest that the seed kernel has high potentials for medicinal applications, while the kernel oil can serve as raw material for many oil related purposes. The oil can be used for human consumption, as well as in the production of industrial products like diodiesel, lubricants, soaps, shampoos and many other cosmetic products.

\section{Compliance with ethical standards}

\section{Acknowledgments}

Our acknowledgment goes to the management of Yusuf Maitama Sule University, Kano who gave full financial, moral and technical support to this research.

\section{Disclosure of conflict of interest}

Some of the materials required for the research had to be obtained from a sister University, and this has not been as easy as it sounds, because it contradicts the policy of our University.

\section{References}

[1] Abu-Al-Futuh IM. (1983). Balanites aegyptiaca: An Unutilized Raw Material Potential Ready for Agro-Industrial Exploitation. UNIDO Document no. 12419 project TF/INT/77/021. UNIDO of the United Nations.

[2] Adegbe AA., Larayetan RA and Omojuwa TJ. (2016). Proximate Analysis, Physicochemical Properties and Chemical Constituents Characterization of Moringa Oleifera (Moringaceae) Seed Oil Using GC-MS Analysis American Journal of Chemistry, 6(2), 23-28.

[3] Adejumo BA, Alakowe AT and Obi DE. (2013). Effect of Heat Treatment on the Characteristics and Oil Yield of Moringa oleifera Seeds. International Journal of Engineering Sciences, 2(1), 232-239.

[4] Afolabi SI. (2008). Chemical Qualities of Oils from Fresh and Market Vegetable Crop Within Kwara State, Nigeria. Nigerian Society of Experimental Biology, 20(2), 71-75.

[5] Alhassan AJ, Muhammad IU, Idi A, Dangambo MA, Ramatu Y, Mohammad A, Nasir A, Yaradua AI, Adamu SM and Alexander I. (2018). Phytochemical Screening and Proximate Analysis of Balanites aegyptiaca Kernel. Food Science and Quality Management, 74, 37-41.

[6] Al-Thobaiti SA and Abu-Zeid IM. (2018). Phytochemistry and Pharmaceutical Evaluation of Balanites aegyptiaca: An Overview Journal of Experimental Biology and Agricultural Sciences, 6(3), 453-465. 
[7] AOAC. (2008). Official Methods of Analysis, Association of Official Analytical Chemists, Washington D.C. (15th ed).

[8] Awe IS and Sodipo OA. (2001). Purification of Saponins of Root of Blighia sapida Koenlg-Holl. Nigerian J. Biochem. Mol. Biol. 16(37), 201-204.

[9] Babeker MA. (2013). Physicochemical Properties of Laloub Seed Oil. M.Sc. Faculty of Agriculture, University of Khartoum, 29-45.

[10] Bayero AS, Datti Y, Shuaibu MM, Nafisatu AM, Asma'u AA, Dikko MA, Zakari AH and Yusuf M. (2019). Phytochemical Screening and Antibacterial activity of the Root Bark Extracts of Neocarya macrophylla). ChemSearch Journal, 10(2), 41-45.

[11] Billore SKV. (1988). Balanites aegyptiaca: A Browse Plant of High Protein Value in Degraded Lands. In: Singh P, Pathak PS (Eds.), Rangelands Resources and Management, 350-355.

[12] British Standard Institute Methods BSI. (1985). Analysis of Oils and Fats, 684.

[13] Brosk FAZ. (2014). Oil properties Laboratory, 2nd stage, Petroleum Engineering Department, Petroleum Engineering Department, Koya University, 4-6.

[14] Chapagain BP, Lindin T, Wiesman Z and Jaroszewski JW. (2006). Structural Analysis of Complex Saponins of Balanites aegyptiaca by 800 MHz 1H NMR Spectroscopy. Magnetic Resonance in Chemistry, 44, 923-928.

[15] Chothani DL and Vaghasiya HU. (2011). A Review on Balanites aegyptiaca Del (Desert Date): Phytochemical Constituents, Traditional Uses, and Pharmacological Activity. Pharmacognosy Reviews, 5, 55-62.

[16] Chung KT, Wong TY, Wei CI, Huang YW and Lin Y. (1998). Tannins and Human Health: A Review. Crit Rev Food Sci Nutr, 38(6), 421-464.

[17] Clement AO, Jacob GA, James MK, Refaat A and Ahmed A. (2011). Harvesting and Processing of Balanite aegyptiaca Leaves and Fruits for Local Consumption by Rural Communities in Uganda. Journal of Food Technology, 9(2), 83-90.

[18] Daya LC and Vaghasiya HU. (2011). A Review on Balanite aegyptiaca Del (Desert Date) Phytochemical Constituents, Traditional Uses and Pharmacological Activity. Journal of Pharmacogn Rev, 5(9), 55-62.

[19] Egbuna C and Ifemeje JC. (2015). Biological Functions and Anti-nutritional Effects of Phytochemicals in Living System. IOSR Journal of Pharmacy and Biological Sciences, 10, 10-19.

[20] Elbadawi SMA, Ahmad EEM, Mariod AA and Mathaus B. (2017). Effects of Thermal Processing on Physicochemical Properties and Oxidative Stability of Balanities aegyptiaca Kernels and Extracted Oil, Grasas Y Aceites, 68(1), 17.

[21] Elseed AMAF, Amin AE, Khadiga A, Ali AA, Sekene J, Hishinum M and Hamana K. (2002). Nutritive Evaluation of some Fodder Tree Species During the Dry Season in Central Sudan. Asian-Australasian Journal of Animal Sciences, 15, 844-850.

[22] Gemechu T, Beyene F and Eshetu M. (2015). Physical and Chemical Quality of Raw Cow's Milk Produced and Marketed in Shashemene Town, Southern Ethiopia. Journal of Food and Agricultural Science, 5(2), 7-13.

[23] Gloria NE, Babajide OE and Ochuko LE. (2011). Activities of some Enzymes, Enzyme Inhibitors and Antinutritional Factors from the Seeds of Sponge Gourd (Luffa aegyptiaca M.). African Journal of Biochemistry Research, 5(3), 86-89.

[24] Guinand Y and Lemessa D. (2001). Reflection on the Role of Wild Food and Famine Foods at a Time of Drough. Wild Foods Plants in Ethiopia. Workshop proceedings. USAID/OFDA. Mombassa, Kenya.

[25] Gupta SC, Shenoy S and Kotecha M. (2012). Pharmacognostical and Phytochemical Evaluation of Balanites aegyptica Del. Stem Bark. International Research Journal of Pharmacy, 3, 169-173.

[26] Gutti B, Bamidele SS and Bagaje IM. (2012). Characterization and Composition of Balanites aegyptiaca Seed Oil and its Potential as Biodiesel Feedstock in Nigeria. Journal of Applied Phytotechnology in Environmental Sanitation, 1, 29-35.

[27] Haftu GA. (2015). Physico-Chemical Characterization and Extraction of Oil from Balanites aegyptiaca Plant (Seed). World Journal of Pharmaceutical Research, 4(11), 1723-1732.

[28] Hanan A, Al-Ashaal AF, Ayman MM, Abd EA and Ali MA. (2009). Phytochemical Investigation and Medicinal Evaluation of Fixed Oil of Balanites aegyptiaca Fruits (Balantiaceae). Journal of Ethnopharmacology, 2, 495-501. 
[29] Harborne JB. (1998). Phytochemical Methods. A Guide to Modern Technique of Plant Analysis. Chapman and Hall London, 260-269.

[30] Jock AA. (2011). Physicochemical and Phytochemical Characterization of Seed Kernel Oil from Desert Date (Balanites Aegyptica) Journal of Chemical Engineering and Bio-Analytical Chemistry, 2(1), 49-61.

[31] Karamat M, Rehana N, Aziz R, Hafiz MF, Muhammad A and Muhammad AA. (2003). Biochemical Analysis of Oil from Seeds of Abutilon muticum. Pakistan Journal of Biological Sciences, 6, 1880-1882.

[32] Kumawat BK, Gupta M, Chand T and Singh Y. (2012). Prelimenary Phytochemical Investigation on Leaves of Balanites aegyptiaca (L.). Research Journal of Pharmaceutical, Biological and Chemical Sciences, 3(2), $762-768$.

[33] Locket CT, Calvert CC and Grivetti LE. (2000). Energy and Micronutrient Composition of Dietary and Medicinal Wild Plants Consumed During Drought. Study of Rural Fulani, Northeastern Nigeria. International Journal of Food Science, 51(3), 195-208.

[34] Manji AJ, Sarah EE and Modibbo UU. (2013). Studies on the potentials of Balanites aegyptiaca Seed Oil as Raw Material for the Production of Liquid Cleansing Agents. International Journal of Physical Sciences, 8(33), 16551660.

[35] Mohamed AA and Mohammed AA. (2018). Extraction and Physico-Chemical Properties of Balanites aegyptiaca (Heglig) Seed Oil Grown In Libya. International Journal of Agricultural Research and Review, 6(2), 674-679.

[36] Mohammed BS, Awatif AM and Azhari HN. (2017). Chemical Composition and Antibacterial Activity of Sudanese Balanites aegyptiaca Del Kernel Oil Chemistry of Advanced Materials, 2(2), 14-21.

[37] Monica B and Ioan S. (2018). Essential Oils from Plants Journal of Biotechnology and Biomedical Science, 1(4), 35-43.

[38] Myles JM. (2001). Methods for the Determination of Specific Gravity, Chandler Engineering Company N. Indianwood Avenue Broken Arrow, Oklahoma, 74012, 22-24.

[39] Obidah W, Nadro MS, Tiyafo GO and Wurochekke AU. (2009). Toxicity of Crude Balanites aegyptiaca Seed Oil in Rats. The Journal of American Science, 5, 13-16.

[40] Ogala H, Elinge CM, Wawata IG, Adegoke A, Muhammad AB and Ige AR. (2018). Extraction and Physicochemical Analysis of Desert Date (Balanite aegyptiaca) Seed Oil. International Journal of Advanced Academic Research, 4(4), 1-12.

[41] Olaofe 0 and Sanni CO. (1988). Nutritional Component of some Non-Conventional Leaf Vegetable Consumed in Cameroon. Food Chemistry, 30, 73-77.

[42] Patel SS and Savjani JK. (2015). Systematic Review of Plant Steroids as Potential Antiinflammatory Agents: Current Status and Future Perspectives The Journal of Phytopharmacology, 4(2), 121-125.

[43] Ratna D, Ujjaini S and Alakananda M. (2014). Extraction of Oil from Crotalaria juncea Seeds in a Modified Soxhlet Apparatus: Physical and Chemical Characterization of a Prospective Bio-Fuel. Fuel, 116, 794-802.

[44] Richardson HG. (1985). Standard Methods for the Examination of Dairy Products. 6th Edition. American Public Health Association, Washington DC, 133-150.

[45] Sara MEF and Mahdi ASS. (2016). Physicochemical Properties of Balanites aegyptiaca (Laloub) Seed Oil. Journal of Biological Science, 2(4).1-10.

[46] Selouka MA, Fouteye MML, Hasni OT, Abdelkarim FM and Ali OMSB. (2020). Phytochemicals, Antioxidant Activity and Ethnobotanical Uses of Balanites aegyptiaca (L.) Del. Fruits from the Arid Zone of Mauritania, Northwest Africa Plants, 9(401), 1-15.

[47] Tripathi IP and Mishra C. (2015). Phytochemical Screening of some Medicinal Plants of Chitrakoot Region, Indian Journal of Applied Research, 5(12), 56-60.

[48] Vaidehi P and Rajesh P. (2016). The Active Constituents of Herbs and their Plant Chemistry, Extraction and Identification Methods: Journal of Chemical and Pharmaceutical Research, 8(4), 1423-1443.

[49] Wail S, Sue TT and Yew AT. (1995). Palm Oil Research Institute of Malaysia. Ministry of Primary Industries. Malaysia. Published by Palm Oil Research Institute of Malaysia.

[50] Yadav JP and Panghal M. (2010). Balanites aegyptiaca (L.) Del. (Hingot): A Review of its Traditional Uses, Phytochemistry and Pharmacological Properties. International Journal of Green Pharmacy, 4, 140-146. 
Datti et al. / GSC Biological and Pharmaceutical Sciences, 2020, 11(03), 197-207

[51] Yubin JI, Miao Y, Bing W and Yao Z. (2014). The Extraction, Separation and Purification of Alkaloids in the Natural Medicine Journal of Chemical and Pharmaceutical Research, 6(1), 338-345.

\section{How to cite this article}

Datti Y, Tijjani YA, Koki IB, Ali UL, Labaran M, Ahmad UU and Tasi'u N. (2020). Phytochemical composition of desert date kernel (Balanites aegyptiaca) and the physical and chemical characteristics of its oil. GSC Biological and Pharmaceutical Sciences, 11(3), 197-207. 